\title{
COGNITIVE STRATEGIES TO ENHANCE ENGLISH LANGUAGE TEACHING IN UKRAINE
}

Цегельська М. В. Когнітивні стратегії як засіб підвищення якості викладання англійської мови в Україні.

Використання англійської мови стає більш динамічним, зважаючи на створення і розширення нових міжнародних мереж зв'язку та розвиток технологій як в англомовних країнах, так i за їх межами. Сучасне суспільство знаходиться в постійному пошуку вдосконалення форм освіти, «підтягування» іiі відповідно до вимог сьогодення. Українська освіта, що знаходиться на порозі нового масштабного реформування, не є винятком. Серед величезного спектру напрямів, які потребують перегляду і вдосконалення, навчання іноземної мови залишається незмінним. Саме навчання іноземної мови може стати потужним засобом формування свідомості, що відбувається шляхом розкриття способів мислення.

У статті висвітлено недоліки традиційного комунікативного підходу, що застосовується у викладанні іноземних мов в Україні, та наголошується на необхідності запровадження нових технологій, які можуть підвищити ефективність навчання англійської мови як засобу міжнародного спілкування, зокрема в опануванні словникового запасу. Ці технології знаходяться у площині когнітивної лінгвістики, яка розглядає мову як когнітивну дію та грунтується на положеннях про те, що мова не $\epsilon$ автономним когнітивним об'єктом, граматика $є$ концептуалізацією, знання мови $\epsilon$ результатом її використання.

Організація матеріалу в когнітивні категорії відбувається через п’ять видів фреймів, що складають фреймову мережу, а саме: предметний фрейм, таксономічний фрейм, посесивний фрейм, акціональний фрейм, компаративний фрейм. Робота 3 концептуальними картами $\epsilon$ складовою начального процесу, який будується пофазово - через імпресинг, меморайзинг, авторизацію та ініціацію.

Ключові слова: комунікативний підхід, когнітивна лінгвістика, академічний словник, фази навчання.

Цегельская М. В. Когнитивные стратегии как средство повышения качества преподавания английского языка в Украине.

Использование английского языка стало более динамичным в связи с созданием и расширением новых международных сетей и стремительным развитием технологий как в англоязычном мире, так и за его пределами. В данной работе оспаривается роль традиционного коммуникативного подхода. Вместо него предлагается подход, основанный на когнитивных механизмах, в котором особое внимание уделяется использованию новых технологий, развитию академического языка и глобальной роли английского.

Ключевые слова: коммуникативный подход, когнитивная лингвистика, академический словарь, фазы обучения.

(C) M. V. Tsehelska, 2016. 
Tsehelska M. V. Cognitive strategies to enhance English language teaching in Ukraine.

The use of English has become increasingly dynamic with the creation and expansion of new international networks of communication and the ubiquity of new technologies in and beyond the English-speaking world. This paper highlights the deficiencies of traditional Communicative Approach to foreign language teaching in Ukraine, and emphasizes the necessity to employ new educational technologies which are more efficient for teaching English as an international language, particularly in the academic sphere.

Key words: communicative approach, cognitive linguistics, academic vocabulary, phases of leaning.

Introduction. With the growth of English as global lingua franca, and exposure to stiff labour markets, many Ukrainian students have revisited their views on education in general and foreign (English) language in particular. Though many of them have been studying English for at least ten years at school and university, they still admit little progress in it. It may be explained by the fact that many courses have been created without taking into consideration how the brain works, how thinking occurs and how it can be used to learn the language. It also explains the interest to cognitive linguistics and cognitive pedagogy that has greatly risen in the recent years. The outcomes of cognitive research may enhance both traditional and modern approaches to teaching English with students' vocabulary enlargement and development of thinking skills. In this article we'll overview the traditional and new methods of teaching English in Ukraine and suggest the ways for their enhancement.

Contemporary globalization processes have made English a lingua franca for today's world. Application of English in new and varied contexts throughout the world causes its rapid development which calls for new approaches to its theoretical studies and its teaching. Though Ukraine tries to implement communicative methods of teaching English as a Foreign Language (EFL) it is still hard to keep pace with the development of global English and new educational technologies applicable in its teaching and learning. Meanwhile, Ukrainian English language learners (ELLs) are challenged with the competitiveness of today's global work-market, which requires a good command of English, and thus necessitates changes in the language classroom.

Drift from communicative to other competences. In the second half of the $20^{\text {th }}$ century, teaching English as a foreign language changed its paradigm, and educators throughout the world focused on developing their students' communicative competence (the term was coined by Dell Hymes 
in 1966). Communicative competence in EFL means that a student is able to produce well-formed utterances to achieve his or her communicative intention in various speech acts - assertive, directive, expressive, etc. On the one hand, communicative competence is grounded on linguistic competence, or one's knowledge of the vocabulary and grammar. On the other hand, communicative competence implies one's acquaintance with the appropriate use of language in variable social contexts.

The Communicative Approach to teaching English (which was a methodological derivative of the theory of linguistic competence) was introduced into the language classroom through simulating students' communication with imaginary native speakers (NS) of English, which takes place in imaginary contexts and for imaginary purposes. Language learning tasks included building vocabulary for greetings, asking directions, using transportation, ordering food in restaurants, etc. Those students who required more detailed language training were supposed to follow an English for Specific Purposes (ESP) sequence, which provides students with linguistic skills necessary for particular professional fields. Introduction of the Communicative Approach triggered development of training materials which focus on typical communicative topics, such as greetings and farewells, weather and seasons, shopping, travelling, professions and hobbies among others. While discussing such topics, students practiced the language via role plays, thus attempting to attain NSlike fluency and raising their ability levels. The examples of respective curricula and textbooks are "Headway" series and "Total English", both popular in EFL contexts and still in use today.

During the previous $20^{\text {th }}$ century, when people became more mobile internationally, the use of English grew exponentially, and it acquired the status of the major international language, or lingua franca, used for communication by speakers who did not share their first language. The response to it in Europe was creation of Common European Framework of Reference for Languages: Learning, Teaching, Assessment (CEFR or $\mathrm{CEF}$ ) - a guideline representing the achievements of learners of foreign languages across Europe and, increasingly, in other countries [2]. The European standard suggests six reference levels for grading foreign language proficiency of an individual, and these levels are considered by the authors of language courses and textbooks. While defining the levels of language proficiency, CEFR relies on a range of competencies (with 
"competence" having acquired the role of a metacategory in language teaching). CEFR distinguishes general competences (descriptive knowledge), and skills, as well as existential competences, including particular communicative competences - such as linguistic competence, sociolinguistic competence, and pragmatic competence. This range of competences partly overlaps with the earlier linguistic competences that served as foundation for a Communicative Approach to teaching English.

Present-day challenges. For Ukraine, English is a necessary prerequisite for a successful integration into global economy, no matter how remote this perspective is. In Ukraine, English is an indispensable part of a secondary school curriculum. However, what matters and what does influence its acquisition is motivation for learning English, and the learners' awareness of the beneficial role of English for both themselves and their country.

At present, English retains its dominant position in industries of business and technology, and its status as a major lingua franca will hardly change is the nearest future. Moreover, it is expected to be further raised with the world market being open for new generations of technical innovations - handheld computers and tablets, Massive Open Online Courses (MOOCs), such as Coursera, Massively Multiplayer Online RolePlaying Games (MMORPGs), etc. Under the circumstances, English becomes a necessary medium for obtaining information and data, and to access the recent achievements in different scholarly fields. Globalization of communication in personal, academic, scholarly, economic and other areas, which will further evolve in the $21^{\text {st }}$ century, as well as emergence of new contexts and places of international cooperation, make teachers of English feel the necessity for updating their educational tools, so as the latter should be compatible with the new challenges of today's life.

Of late, EFL students have been increasingly enrolling in higher education in English speaking countries. In 2014, approximately 733,000 international students enrolled in institutions of higher education in the United States [6], which is a $6 \%$ increase as compared with the previous year. Yet, many students are not properly prepared to meet the strong demand for sufficient competence in academic English. For example, students, like those in Ukraine, where EFL is taught via application of the Communicative Approach, are faced with a mismatch between their communicative competence and the type of language required in academic 
and scholarly fields. This mismatch exposes inadequacy of simulated interactions with imaginary native speakers in imaginary settings, which may have only a distant resemblance to real on-line interaction of native and nonnative speakers of English. Another problem is attaining appropriate instruction in academic and professional English sufficient for passing an exam like GRE (Graduate Record Exam), obtaining a university degree and getting employed after graduation.

Present-day facilities for ELLs. Teaching English to contemporary students should be grounded on the contemporary needs. The entrenched Communicative Approach with its traditional methods should not be discarded, but it should be integrated into a broader spectrum of newly developed teaching techniques. The latter should be aimed at developing students' skills sufficient for both oral and written communication with real native and non-native speakers of English. Nowadays, such skills can be developed to some extent outside the language classroom. Students use English to have an access to online games and social networks (FaceBook, Instagram, as an instance), they use search engines for information, conduct research, watch videos (on YouTube), listen to audio samples, and read and write blogs. They use abbreviated English in text and chat messages (LOL, NVMD, JK, NP). They also de-code semiotic systems in gaming and advertising, thus exposing that, which in 1996 was dubbed "multiliteracies" by the New London Group. Such literacies include decoding semiotic systems, as players do rapidly in MMORPGs. In online gaming, players are more likely to read the meaning behind symbols (e.g., treasure chests, pictures, maps, avatars) than behind words.

The $21^{\text {st }}$ century EFL students are less likely to use static, printed textbooks than ever before. In Ukraine, many of such textbooks are outdated (published before 1991), but their replacement is expensive and therefore unaffordable. Access to multimedia technologies enables students to obtain up-to-date information without being heavily dependent on the printed sources.

At the end of the last century, when the Communicative Approach was gaining momentum, ELLs started to formulate questions as to the goals of English in Ukraine, the purposes of its learning, and the needs which it has to satisfy. At present, the answers to many of these questions seem to be obvious: first and foremost, English has to satisfy students' academic needs. Therefore, one of the contemporary demands is English for 
advanced academic purposes. However, Ukraine has no tradition in teaching it. Today, English language instruction should include courses of Academic English, which will make Ukrainian students capable to successfully cope with the international English language proficiency tests, such as GRE (Graduate Record Exam), TOEFL (Test of English as a Foreign Language) or IELTS (International English Language Testing System). These tests are indiscriminate to the learner: EFL students are expected to have the proficiency level similar to that of native speakers. Such tests is a part of the new reality.

Absence of solid courses in Academic English taught at Ukrainian high schools and universities is partially compensated by students' access to open online courses (MOOCs), which, on the one hand, help many young Ukrainians to enter the best world universities, and on the other hand, demonstrate what kind of English has to be taught in Ukraine. One of the top Ukrainian technical universities, "NTU Kyiv Polytechnical Institute" on its website encourages students to take 25 on-line courses in English, among them Computer Science, Software Engineering, HumanComputer Interfaces, and Machine Learning. Comments posted by students who had taken these courses expose the problems which they encounter: incomprehensibility of some lecturers' English, specific vocabulary, interruption of the lecture with tests for its understanding, etc. These comments pinpoint the issues to be included into the course of Academic English, which should focus not only on the vocabulary and grammar typical of different academic genres, but also on the composition of academic texts and a variable manner of oral academic presentations.

Enhancing English language teaching in Ukraine. To test knowledge of school- leavers, Ukrainian system of secondary education employs the External Independent Testing (EIT), similar to GSCE in the UK and ACT or SAT in the US. Independent testing in English, as a part of EIT, was developed on the grounds of International English Language tests, particularly the FCE - the First Certificate in English Cambridge test (level B2 in the Common European Framework). However, due to technical difficulties, Ukrainian EIT has retained only the reading, writing and English use sections, and has omitted the listening and speaking sections. The first test, held in 2009, showed great discrepancy between English learned at school and English required by the EIT. The major concern was the low level of performance, which is partly explained by outdated 
textbooks written by proponents of the Communicative Approach and focused on the initial acquisition of English through reading texts which provide the vocabulary and grammar.

Vocabulary that remains most difficult for acquisition may be greatly enhanced by the outcomes of cognitive linguistics that suggest grouping vocabulary in concept maps instead of two modern approaches to text book writing - one is a lexical syllabus that is based on the words that appear with a high degree of frequency in spoken and written English. The other is based on the importance of lexical chunks in the acquisition of language and achieving fluency.

Cognitive linguistics views the language as a kind of cognitive action and is based on three major hypotheses:

- language is not an autonomous cognitive faculty;

- grammar is conceptualization;

- knowledge of language emerges from language use [5, p. 12].

The process of speaking and understanding a language involves memory, attention and judgment. Memory helps to organize linguistic knowledge into categories, attention activates conceptual structures and judgment or comparison is a part of categorization process.

As a result of comparison or categorization our brain produces cognitive categories, which "involves comparison of the prior experience, judging it to belong to the class of prior experiences to which the linguistic expression has been applied" [5, p. 54]. Concepts do not exist separately in our mind but are brought together into conceptual systems by experience and contain non-linguistic information [5, p. 12].

While learning a foreign language a child builds constructions in their head, these constructions are based on the most schematic categories of thought arranged into frames in accordance with the ways we perceive things of the experienced world [1, p. 13].

Analysis of multiple lexical, derivational, and syntactic data makes it possible to presume that the basic frames are five in number, and they include propositional schemas whose types are defined by the frames they belong to. Being schemas - quantitative, qualitative, locative, temporal, and mode of being - belong to the Thing Frame. Action schemas - state / process, contact, and causation - belong to the Action Frame. Possession schemas - part-whole, container-content, and ownership - belong to the Possession Frame. Identification schemas - personification, classification, 
and particularization - belong to the Identification Frame. Comparison schemas - identity, similarity, and likeness - belong to the Comparison Frame. [1, p. 18].The schemas, limited in number, serve as a conceptual foundation of derivational and syntactic meanings, and they are applicable for construing unlimited configurations of conceptual networks, which structure meanings of individual linguistic units and semantic spaces of the groups of such units. Such frames help the teachers of language structure the information and develop a number of useful techniques for teaching language.

After the concept map is built, it becomes a part of general language learning, that is most effectively built on the cognitive model on the phases of the knowledge processing was developed by M. Karpenko, who defined the interdependence between the neurophysiological mechanisms and the principles of building the curriculum, which should be built on four phases - impressing, memorizing, authorization and initiation [3, p. 43].

The first phase called "impressing" allows building the schematic neuronet in the brain and forms the motivation to learning. At this stage we can only give the scheme of the topic we are going to teach. At the second stage a new neuronet is being formed with the help of various exercises, listening and watching films, working with computer programs, etc. The third stage - authorization will edit the neuronet in the brain and at this stage we can start asking students to display the knowledge they got by making presentations, giving talks, reports or participating in the seminars. At the fourth stage the official representation of knowledge is relevant - it is the time for tests and grades [3, c. 167].

In the real classroom we often omit the second and third stages thus making the knowledge unauthorized by the brain. The whole conception brings us to the following questions: how to build the constructions (mindmaps or any other kinds of schemes) so that the revision and recycling of knowledge were meaningful. It can be done if we consider the already mentioned theory of the basic frames by S. Zhabotynska [1], which states that the foundations of our information system are structured by the most schematic categories of thought arranged into frames in accordance with the ways we perceive things of the experienced world. They form a network structured by a limited set of iterative propositions (propositional schemas) that belong to the five basic frames - the Thing, Action, Possession, Identification, and Comparison frames. Such networks create 
ontologies, which can be later referred to as a basis for revision and formation of critical thinking skills in leaners.

In general any English language curriculum can be built according to the following principles:

- All vocabulary is compiled into conceptual models, defined as concept maps or ontologies, that are actually multidimensional "networksin-the-networks" structures;

- On the basis of these models thinking-oriented tasks are developed;

- Curriculum development takes into consideration the four phases of learning - impressing, memorizing, authorization and initiation.

Introduction of these principles into English language learning will allow out students to develop higher order thinking skills and use the language more effectively.

Conclusion. New spaces for English language use using new mediums for communication insist that teachers must be prepared to introduce, use, critically analyze, and teach these spaces to EFL students. Vocabulary teaching and learning is a cycle of semantization and internatiolization, which is closely linked to how the word is presented. The introduction of the cognitive science outcomes such as concept mapping and stages of learning will attend to the specialized and academic language that students need, and uses $21^{\text {st }}$ century literacies and technologies. Usage of cognitive strategies in teaching a foreign language will contribute directly to not only language acquisition, but also to the student's development.

\section{Literature}

1. Жаботинская С. А. Концептуальний анализ: типы фреймов / С. А. Жаботинская // Вісник Черкаського університету. - Сер. Філологічні науки. - 1999. - Вип. 11. C. $12-25$.

2. Загальноєвропейські Рекомендації з мовної освіти : вивчення, викладання, оцінювання / [наук. ред. укр. вид. С. Ю. Ніколаєва]. - К. : Ленвіт, 2003. - 273 с.

3. Карпенко М. П. Телеобучение / М. П. Карпенко. - М. : Современная гуманитарная академия (СГА), 2008. $-800 \mathrm{c}$.

4. Оцінювання навчальних досягнень учнів 3 англійської мови за результатами тестування 3НО. Accessed May 4, 2013 from http://loippo-monitoring.edukit.lg.ua/zno/

5. Croft W. Cognitive Linguistics / W. Croft, A. D. Cruse. - New York : Cambridge University Press, 2004. - 374 p.

6. McMurtrie B. International enrollments at U. S. colleges grow but still rely on China / B. McMurtrie // Chronicle of Higher Education. - Nov. 14. - Accessed April 8, - 2013. From : http://chronicle.com/article/International-Enrollments/129747/

Стаття надійшла до редакиії 03.12.2015 p.

(C) M. V. Tsehelska, 2016. 